\title{
Econometric Evidence on the Impacts of Privatization, New Entry, and Independent Industry Regulator on Mobile Network Penetration and Expansion
}

by

\author{
Yan Li \\ ESRC Centre for Competition Policy, University of East Anglia
}

\section{CCP Working Paper 08-35}

\begin{abstract}
This study examines the impacts of reforms - privatization, new entry and independent regulatory authority - on mobile network penetration and expansion using a new and hitherto unused panel dataset for 30 national mobile markets (i.e. 29 OECD countries and China) over the time period 1991-2006 under a 3-equation econometric framework. The estimation results confirm that introducing new entry is, in general, positively correlated with mobile network penetration and expansion; and in particular, the third entry brings many more benefits than the second one. The results also highlight the crucial role of an independent regulator in privatized mobile markets. Especially, the dynamic estimation results suggest that without an independent regulator, privatization is, on average, negatively correlated with mobile network expansion, even in certain competitive market environments.
\end{abstract}

December 2008

JEL Classification Codes: L10, L51, L96, K23

Keywords: New entry; privatization; independent regulator; mobile network; econometric analysis 


\section{Acknowledgements:}

I would like to thank Catherine Waddams, Bruce Lyons and Stephen Davies for comments and discussions. Suggestions from the participants of the conference in Evolving Marketing Competition in the $21^{\text {st }}$ Century, Mainz, 2008, and EARIE 2008, and the Competition Law and Economics European Network (CLEEN) New Researchers Workshop, Norwich, 2008, are greatly appreciated. Support of the Economic and Social Research Council is also gratefully acknowledged.

Contact details:

Yan Li, ESRC Centre for Competition Policy, University of East Anglia, Norwich, Norfolk, NR4 7TJ, UK

li.yan@uea.ac.uk 


\section{Introduction}

This paper provides econometric evidence on the results of telecommunication reforms. It builds on previous work by studying newly available data in thirty mobile network markets and by exploring in detail new entry effects alongside the effects of privatization and independent regulator. In contrast to previous empirical work on fixed-line penetration (see Ros, 1999, 2003; Wallsten, 2001, 2004; Fink et al., 2001; McNary, 2001; Li and Xu, 2002, 2004), however, this study examines mobile network penetration effects. There are two main motivations to focus on the mobile network market. First, with continuous advance in the wireless network technology, the mobile network sector is now the most dynamic sector in telecoms in the world, and the mobile network services have proved formidable substitutes for fixed lines. The International Telecommunication Union (ITU) (2007) statistics show that while the global fixed-line markets have shown stagnation with a low world average fixedline penetration rate at $20 \%$ since 2005 and an actual decrease by almost $5 \%$ in 2007, the global mobile markets remain strongly growing with a new record for the world average mobile penetration rate at $49 \%$ in 2007 , representing some $20 \%$ increase year-on-year. More specifically, the number of fixed lines per 100 inhabitants has actually been falling since 2001 when it reached its peak at 57 in the developed world, and it only grows at a very low average rate - below one per cent - year-by-year since 1997 in the developing world (standing at a very low level, 16 lines per 100 inhabitants, in 2007). Mobile penetration, in contrast, shows continuous and vigorous growth in both the developed and developing world, with the average annual growth rates at around $20 \%$ and $48 \%$ over $1997-2007$ time periods, and reached $97 \%$ and $45 \%$ by the end of 2007 (ITU 2007). Therefore, presently, the mobile market is better able to capture the dynamics of the telecom sector around the world. Second, econometric evidence on the effects of mobile sector reforms is scarce, since data availability is severely limited by the fact that reforms in the mobile network sector occurred relatively recently. Only now is there sufficient time lapse since the reforms were first implemented in the worldwide mobile markets for enough data to be available for econometric analysis. Specifically, I use national level mobile market data from 29 OECD countries and China over the time period 1991-2006. ${ }^{1}$

\footnotetext{
1 Both telecom reforms and mobile markets in most OECD countries have experienced relatively longer time of developments; some of them are even the leading countries in terms of both telecom reforms and mobile network
} 
As with other utility reforms, the telecommunication reforms studied in the existing literature typically include three dimensions: privatizing the state-owned telecom providers, introducing competition, and establishing an independent industry regulator. There is a general consensus that competition is likely to be the most effective method of improving telecom performances. This consensus is supported by studies that have found that competition is associated with higher teledensity and productive efficiency, lower service price and better service quality (Boylaud and Nicoletti, 2000; Fink et al., 2001; Laffont and Tirole, 2000; Li and Xu, 2002, 2004; McNary, 2001; Ros, 2003; Wallsten, 2001, 2004); and that the success or failure of privatization is highly dependent on political and economic environments in general and the post-privatization regulatory framework in particular (Levy and Spiller, 1994, 1996; Villalonga, 2000; Yarrow, 1986). A survey of the privatization study by Megginson and Netter (2001) suggests that, on balance, deregulation and liberalization in the telecom sector are associated with significant improvements in performance and efficiency, but the impact of privatization alone is less clear. It also suggests that the combination of privatization and deregulation/liberalization is positively correlated with telecom performances. Parker and Kirkpatrick's (2005) recent review of empirical literature on privatization also concludes that "if privatization is to improve performance over the longer term, it needs to be complemented by policies that promote competition and effective state regulation, and that privatization works best when it is integrated into a broader process of structural reform".

Since the late 1990s when reformers in Eastern Europe and the former Soviet Union recognized that ignoring the institutional and competitive framework was a mistake in the method of reforming state-owned enterprises (i.e. massive privatization only), ${ }^{2}$ many countries around the world have been establishing an industry-level independent regulatory agency to promote competition and effective regulation in their utilities. Since then, the impact of the existence of an independent regulator on industry performance has been fiercely debated and this specific issue

development in the world (ITU, Trends in Telecommunication Reform 2004/2005). Also, the Chinese mobile network market cannot be ignored in the analysis, as it has been largely regarded as one of the fastest growing market in the world with the highest mobile subscribers and the largest potential markets. Therefore, both regulatory indicators and operating performance indicators for these national mobile markets are available at more complete and extensive panel level, which allows econometric analysis of the reform effects more thoroughly.

${ }^{2}$ In the early 1990s, many influential advisers recommended fast privatization in Eastern Europe and the former Soviet Union as the only realistic method of reforming state-owned enterprises. 
has been investigated in numerous studies, with reference both to telecommunications and other utility sectors (Gual and Trillas, 2003; Gutierrez and Berg, 2000; Guttierez, 2003a, 2003b; Cubbin and Stern, 2006; Stern and Holder, 1999). These studies focus on identifying the characteristics of regulatory institutions in evaluating the quality of overall regulatory governance that tends to be associated with higher levels of certain performance measures, such as fixedline penetration or electricity generation. The findings of these studies are broadly consistent in showing that one of the crucial institutional elements bearing on good regulatory governance is the existence of a strong and independent judiciary separate from industry operators and other governmental bodies - which is able to make decisions independently and is backed by legislation rather than executive decree. However, the existing literature does not, with rare exception, pay much attention to the explicit effects of this crucial institutional element - an independent regulator, per se - on the performance of telecoms in general and of the mobile network sector in particular. ${ }^{3}$

This empirical study takes a new and closer look at the relationship between the mobile reforms and its network penetration and expansion, by paying explicit attention to issues that were sometimes neglected in previous studies of telecom reforms, for example, the role of an independent regulator, per se. In addition, the mobile network market is obviously more competitive than the fixed-line market, since continuous advance in the wireless technology lowers, to a large extent, the sunk costs, allowing new firms to roll out mobile network services. Therefore, instead of testing the rough effect of competition using either a binary dummy variable (e.g., Ros, 1999, 2003; Fink et al., 2001) or indirect proxies of competition in other telecom segments (e.g., Li and Xu, 2002, 2004; Wallsten, 2001, 2004), I evaluate more detailed and direct effects of each new entry into a mobile network market using a set of actual entry dummies. ${ }^{4}$ Meanwhile, I examine the effect of

\footnotetext{
${ }^{3}$ From my knowledge, to the date this study is conducted, only one paper by Maiorano and Stern (2007), using data from low and middle-income countries over a 15-year period of 1990-2004, takes a look at the relationship of regulatory institutions and performances in the mobile telecommunications sector, with actually focusing much more on the institutional setting within which the new regulator agencies operate. Their results show some evidence that the existence of an autonomous industry regulator increases the mobile penetration rate. However, they also note that the less robust results suggest that the role of regulator is not as crucial for mobile operators as it is in the fixed-line market.

${ }^{4}$ The actual entry dummies are measured by the actual number of mobile network operators in a market year-by-year. And any new entries are recorded one year after commencing their services in the market, which is the year effective competition was observed (same method is applied in recording all other regulatory reform variables). In the set of entry dummies, monopoly is used as base dummy, and dumentry2 equals one if a second mobile network operator enter the market, and equals zero, otherwise; dumentry3 equals one if a third mobile operator enter the market, and equals zero, otherwise; and so on.
} 
privatization by itself and its interactive effect with the independent regulator in such competitive environments to disentangle the complex privatization effects, and thus, to understand the nature of privatization. Further, this analysis is conducted under a newly developed econometric framework - a 3-equation structural model - based on Griliches (1957) logistic growth model, in addition considering potential endogeneity with mobile service price and labour productivity.

The estimation results confirm that in general, introducing new entry is the most effective method of promoting mobile network penetration and expansion, and highlight the crucial role of an independent industry regulator in accompanying the privatization of mobile network incumbents. In particular, the third-to-fifth entries are jointly associated with the highest mobile penetration, and the third entry is also associated with the fastest network expansion. Without an independent regulator, privatization is, however, associated with few benefits to mobile penetration, and even shows, on average, a significantly negative correlation with network expansion. Furthermore, the results also imply that the mobile service price and labour productivity partially mediate the effects of regulatory reforms, in particular, of the new entry and independent industry regulator. Such mediation effects suggest that those reforms affect network penetration and expansion partially through their effects on price reduction and labour productivity improvement.

The remainder of this paper is structured as follows. The next section presents the hypotheses. Section III describes the data. Section IV elaborates the econometric methodology, including model developments, variable descriptions, and model approaches. Section V presents and discusses the estimation results. Section VI concludes the paper with remarks and policy implications.

\section{Hypotheses}

Building on the findings of literature cited in the above section, I expect the following reform effects on mobile penetration. First, according to the general consensus of the positive effect of competition, I have

Hypothesis 1: The mobile penetration will increase if a second competitor enters a mobile market. 
Second, regarding the impact of the number of competitors in a market, the previous empirical work has little evidence. Besides, economic theory does not give a solitary simple prediction. For instance, based on the classic Bertrand competition model,${ }^{5}$ a duopoly is enough to drive down price to the marginal cost and results in perfect competition - meaning that there is no difference between the second entrant and the following entries. In contrast, based on the Cournot competition model, ${ }^{6}$ the perfect competitive level cannot be reached by duopoly market structure, but with many entries into the market - meaning that allowing a third or more entries into the market is also of importance. Furthermore, according to the Cournot model, there appears to be an incentive for firms to tacitly collude using self-imposing strategies to reduce output so as to raise the price and thus increase profits for all firms involved. Therefore, when more firms are allowed to enter the market, better performance (e.g. lower price and higher output) can be obtained, as it becomes more difficult for tacit collusion to be executed. To explore in detail the impact of each entry empirically, I used a set of entry dummy variables and examine the hypothesis below.

Hypothesis 2: The growth of mobile penetration will be enhanced by each new entry into a market

Third, the effect of privatization alone was unclear or inconsistent in the existing literature. But, its effect can be positive when privatization is complemented by policies that promote competition. Given that the mobile network markets are generally competitive, in this study, I expect

Hypothesis 3: The mobile penetration will increase, if the mobile incumbents are privately owned. And,

Hypothesis 4: The interaction of the number of entrants and privatization will enhance the increase in mobile penetration.

Fourth, considering the importance of independent industry regulator to good regulatory governance that may enhance certain performances, I expect Hypothesis 5: The mobile penetration will be higher in a market having an independent regulator than that without one.

\footnotetext{
${ }^{5}$ Bertrand model is a price competition model. It works better if capacity and output can be easily changed.

${ }^{6}$ Cournot model is a quantity competition model. It works better if output and capacity are difficult to adjust.
} 
Finally, since theory also suggests that privatization needs to be complemented by effective regulatory framework to generate telecom improvements, I have Hypothesis 6: The interaction of an independent regulator and privatization will positively affect mobile penetration; better growth in mobile penetration will be obtained if there is an independent regulator in privatized markets than if there is not.

\section{Data}

I compile a national-level panel dataset based on a variety of sources for 29 OECD countries and China over the time period 1991-2006. This panel dataset contains sufficient information on telecom performance indicators, mobile sector reform variables, and selected national macro-data to allow me to conduct econometric analysis on the effects of mobile sector reforms, and specifically, to explore the relationships between privatization, new entries and independent industry regulator and mobile network penetration and expansion.

The primary telecom performance indicators, coming mainly from the International Telecommunications Union (ITU), include mobile penetration (i.e. the number of mobile subscribers per 100 inhabitants), mobile price of a 3-minute local call, fixedline price of a 3 -minute local call, ${ }^{7}$ fixed-line penetration (i.e. the number of main lines per 100 inhabitants), and mobile labour productivity (i.e. the number of mobile subscribers served per mobile staff). ${ }^{8}$ I use the mobile penetration measure as the main dependent variable on which the effects of reforms are tested. Mobile and fixed-line prices, fixed-line penetration and mobile labour productivity are used as demand (the former three) and supply (the last one) factors that may affect mobile penetration.

The reform variables include (1) a privatization dummy that equals one if at least $50 \%$ of assets were held by the private sector, and equals zero otherwise; (2) an

\footnotetext{
${ }^{7}$ Prices are adjusted by PPP (referring to current exchange rate to USD\$) and the inflation.

${ }^{8}$ ITU database did not provide information on the number of mobile staffs in China. I complement that by reviewing the telecommunications annual reports offered by the Ministry of Information Industry of China (MII).
} 
independent regulator dummy that equals one if the regulatory agency was created backed by legislation and claimed to be independent from other political power, i.e. to make its decisions without being subject to any other governmental bodies, and equals zero if any one of these two conditions fails; (3) a set of entry dummies (using monopoly as the base dummy) - dumEntry2 equals one if a second mobile network operator enters a market, and equals zero otherwise; dumEntry3 equals one if a third mobile network operator enters a market, and equals zero, otherwise; and so on; and (4) a regulation dummy that equals one if the country passed the reform-related telecom legislation, and equals zero otherwise. ${ }^{9}$ These reform variables are measured based on the countries' information on (1) the year and level at which their incumbent mobile network operators were privatized, (2) the year and conditions when an independent regulatory authority was established, (3) the actual number of mobile network operators (MNOs) in the national markets year-by-year, and (4) the year that the reform-related telecom legislation was passed. This information is primarily extracted from the ITU-BDT ${ }^{10}$ and the World Bank's ${ }^{11}$ online telecom regulatory databases, with complements of time-series data on the number of MNOs from the OECD (for data from 1990 to 2000) and from countries' telecom regulators' websites as well as from some MNOs' websites (for data from 2000 to date).

The national macro-data include GDP per capita, national population and urban population ratio (i.e. the population living in an urban area as a percentage of total national population), used as other exogenous control variables. These macroeconomics and demographic statistics are available online from the Organisation for Economic Co-operation and Development (OECD), the International Monetary Fund (IMF) and the World Bank Group - Health Nutrition \& Population statistics (WBG-HNP).

\footnotetext{
${ }^{9}$ Given the existence of a substantial time-lag between the government's announcement of a policy and an observed result, some researchers (e.g. Fink et al., 2001) have considered to apply one-year-lag effect of policy changes in their studies. For instance, they used to record privatization not in the year it was announced by government but in the next year the sale of equity was completed; moreover, if the sale was completed relatively late in the year, they treat the privatization as effective from the following calendar year. Similarly, they observed the effective competition not in the year the new operators just commenced services if they entered the market relatively late in that year, but in the following year. I follow this idea plus a consideration of the time of learning by doing for new entries in this study. Therefore, as a rule, I record all reform variables as effective from the following year they occurred, since it is the least ambiguous criterion that they can take effects in the following year. In doing so, for example, I observe privatization in a given year was taken as effective from the following year; observe any entries in the following year they commenced services in the markets; and record the starting year of an independent regulator as one year after it was established.

${ }^{10} \mathrm{BDT}$ - the ITU development sector named the Telecommunication Development Bureau.

${ }^{11}$ See the WB's telecommunications regulation database and the WB-IFC's privatization database, are available on http://econ.worldbank.org/WBSITE/EXTERNAL/EXTDEC/EXTRESEARCH/0,,contentMDK:20699152 pagePK:64214825 piP K:64214943 theSitePK:469382,00.html and http://rru.worldbank.org/Privatization/ respectively.
} 
Table 1 shows the trends in both the performance and the reform indicators over the period 1991-2006 (i.e. calculated means across 30 countries by year). The statistics demonstrate that on average, mobile penetration increases continuously along with the increasing prevalence of mobile sector reforms across countries. ${ }^{12}$ There is, also, a clear trend of fixed-mobile usages substitution. Since 2000 when the average mobile penetration exceeded, for the first time, the average fixed-line penetration, it has now doubled the fixed-line penetration. The cross-country fixedline penetration, in contrast, continues to decrease since 2000 when it reached its peak at an average rate of $50.83 \%$. In addition, following the mobile sector reforms, there is an upward tendency in the mobile labour productivity across countries, with a $40 \%$ average annual growth rate. Also, there is, on average, a downward tendency in the mobile services price (i.e. 3-minute peak rates of mobile local calls), with an average annual decrease rate of $2 \%$.

Table 1: Summary Statistics for Cross-Country Trends in Telecoms Performances and Reforms (1991-2006)

\begin{tabular}{|c|c|c|c|c|c|c|c|c|c|c|}
\hline \multirow[t]{2}{*}{ year } & $\begin{array}{c}\text { Mobile } \\
\text { penetration }\end{array}$ & $\begin{array}{l}\text { Fixed-line } \\
\text { penetration }\end{array}$ & $\begin{array}{c}\text { Mobile } \\
\text { subscribers } \\
\text { per staff }\end{array}$ & $\begin{array}{c}\text { Mobile } \\
\text { price of } \\
\text { 3-min } \\
\text { local call } \\
\text { (USD) }\end{array}$ & $\begin{array}{l}\text { Number } \\
\text { MNOs }\end{array}$ & $\begin{array}{c}\text { Mobile } \\
\text { incumbents } \\
\text { privatized }\end{array}$ & $\begin{array}{l}\text { Independent } \\
\text { regulator } \\
\text { established }\end{array}$ & $\begin{array}{c}\text { Reform } \\
\text { legislation } \\
\text { passed }\end{array}$ & $\begin{array}{c}\text { Privatization } \\
\qquad \& \\
\text { independent } \\
\text { regulator }\end{array}$ & \multirow[t]{2}{*}{ Freq. } \\
\hline & \multicolumn{9}{|c|}{ Mean } & \\
\hline 1991 & 1.66 & 39.21 & 5.91 & 1.36 & 1 & $17 \%$ & $20 \%$ & $57 \%$ & $10 \%$ & 30 \\
\hline 1992 & 2.11 & 40.40 & 10.50 & 1.44 & 1 & $20 \%$ & $20 \%$ & $60 \%$ & $10 \%$ & 30 \\
\hline 1993 & 2.88 & 41.60 & 23.40 & 1.38 & 1 & $23 \%$ & $23 \%$ & $67 \%$ & $10 \%$ & 30 \\
\hline 1994 & 4.49 & 42.84 & 48.84 & 1.40 & 2 & $27 \%$ & $27 \%$ & $70 \%$ & $10 \%$ & 30 \\
\hline 1995 & 7.14 & 44.10 & 74.32 & 1.42 & 2 & $33 \%$ & $30 \%$ & $70 \%$ & $10 \%$ & 30 \\
\hline 1996 & 11.03 & 45.53 & 105.36 & 1.45 & 2 & $37 \%$ & $30 \%$ & $77 \%$ & $13 \%$ & 30 \\
\hline 1997 & 15.91 & 47.38 & 127.20 & 1.31 & 2 & $50 \%$ & $37 \%$ & $80 \%$ & $23 \%$ & 30 \\
\hline 1998 & 24.22 & 48.27 & 184.38 & 1.22 & 2 & $60 \%$ & $60 \%$ & $90 \%$ & $37 \%$ & 30 \\
\hline 1999 & 37.57 & 49.79 & 227.31 & 1.04 & 3 & $83 \%$ & $67 \%$ & $90 \%$ & $57 \%$ & 30 \\
\hline 2000 & 52.87 & 50.83 & 305.72 & 0.94 & 3 & $83 \%$ & $70 \%$ & $97 \%$ & $60 \%$ & 30 \\
\hline 2001 & 63.85 & 50.47 & 373.79 & 0.77 & 3 & $87 \%$ & $80 \%$ & $100 \%$ & $70 \%$ & 30 \\
\hline 2002 & 70.09 & 50.09 & 405.08 & 0.89 & 3 & $87 \%$ & $83 \%$ & $100 \%$ & $73 \%$ & 30 \\
\hline 2003 & 76.15 & 49.30 & 466.44 & 0.99 & 3 & $87 \%$ & $87 \%$ & $100 \%$ & $77 \%$ & 30 \\
\hline 2004 & 83.72 & 48.81 & 511.24 & 0.98 & 4 & $87 \%$ & $87 \%$ & $100 \%$ & $77 \%$ & 30 \\
\hline 2005 & 90.30 & 47.34 & 542.67 & 1.00 & 4 & $87 \%$ & $87 \%$ & $100 \%$ & $77 \%$ & 30 \\
\hline 2006 & 96.79 & 46.87 & 586.14 & 1.00 & 4 & $87 \%$ & $87 \%$ & $100 \%$ & $77 \%$ & 30 \\
\hline $\begin{array}{c}\text { Average annual } \\
\text { change rate }\end{array}$ & $33 \%$ & $1 \%$ & $40 \%$ & $-2 \%$ & $8 \%$ & $12 \%$ & $11 \%$ & $4 \%$ & $17 \%$ & \\
\hline
\end{tabular}

Data source: author compiled based on a variety of sources, including ITU database on the world telecommunication/ICT indicators (2006), ITU-BDT online regulatory information database, OECD regulatory database (2000), countries' regulatory websites and mobile network operators' websites.

\footnotetext{
${ }^{12}$ Also, see Appendix C for the correlations with significant levels between regulatory reforms and the mobile penetration, as well as the average mobile penetration by different reform practices.
} 
Table 2 presents summary statistics for the information of mobile sector reforms by country. It lists the years in which mobile incumbents were privatized, reform legislations were passed and independent regulators were established as well as the actual number of mobile network operators (MNOs) by $2006 .{ }^{13}$ The statistics show that to date, all thirty sample countries have passed the reform-related telecom legislation, following the latest one from this sample, China, which passed its "Telecommunications Regulations of the People's Republic of China" on 25 September, 2000. In general, mobile competition tends to be fairly intense across countries. By 2006, almost all national mobile markets have three to six MNOs each except China, New Zealand and Norway where just two MNOs compete for their markets. Most countries privatized their incumbent MNOs in the late 1990s, except China, Koran, Mexico and Turkey where the mobile incumbents are still stateowned. By 2002, 26 out of 30 countries established an independent regulator. Eighteen of them were established before or at least at the same time as the countries' incumbent MNOs were privatized. So far, only China and Japan have no separate regulator at all, while in Denmark and Switzerland the separate regulators are not independent.

Table 2: Summary Statistics for Mobile Sector Reforms by County

\begin{tabular}{|c|c|c|c|c|c|c|c|c|c|}
\hline Country & $\begin{array}{c}\text { Year } \\
\text { incumbents } \\
\text { privatized }\end{array}$ & $\begin{array}{c}\text { Year } \\
\text { independent } \\
\text { regulator } \\
\text { established }\end{array}$ & $\begin{array}{c}\text { Year } \\
\text { reform } \\
\text { legislation } \\
\text { passed }\end{array}$ & $\begin{array}{l}\text { Number } \\
\text { MNOs } \\
\text { by } 2006\end{array}$ & Country & $\begin{array}{c}\text { Year } \\
\text { incumbents } \\
\text { privatized }\end{array}$ & $\begin{array}{c}\text { Year } \\
\text { independent } \\
\text { regulator } \\
\text { established }\end{array}$ & $\begin{array}{c}\text { Year } \\
\text { reform } \\
\text { legislation } \\
\text { passed }\end{array}$ & $\begin{array}{r}\text { Number } \\
\text { MNOs } \\
\text { by } 2006\end{array}$ \\
\hline Australia & 1997 & 1997 & 1974 & 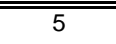 & Japan & always & $\overline{\mathrm{n} / \mathrm{a}}$ & 1984 & 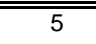 \\
\hline Austria & 1998 & 1997 & 1987 & 4 & Korea & $\mathrm{n} / \mathrm{a}$ & 1997 & 1983 & 3 \\
\hline Belgium & 1996 & 1993 & 1991 & 5 & Luxembourg & 1998 & 1997 & 1997 & 3 \\
\hline Canada & always & 1976 & 1985 & 6 & Mexico & $\mathrm{n} / \mathrm{a}$ & 1996 & 1990 & 4 \\
\hline China & $\mathrm{n} / \mathrm{a}$ & $\mathrm{n} / \mathrm{a}$ & 2000 & 2 & Netherlands & 1994 & 1997 & 1988 & 6 \\
\hline Czech Republic & 1994 & 2000 & 1999 & 4 & New Zealand & always & 2001 & 1986 & 2 \\
\hline Denmark & 1991 & dep. & 1995 & 4 & Norway & 1998 & 1987 & 1995 & 2 \\
\hline Finland & 1998 & 1988 & 1987 & 4 & Poland & 1998 & 2000 & 1990 & 3 \\
\hline France & 1997 & 1997 & 1990 & 4 & Portugal & 1995 & 1989 & 1989 & 3 \\
\hline Germany & 1996 & 1998 & 1996 & 4 & Spain & 1992 & 1996 & 1987 & 3 \\
\hline Greece & 1996 & 1992 & 1994 & 3 & Sweden & 2000 & 1992 & 1993 & 4 \\
\hline Hungary & 1993 & 1999 & 1992 & 3 & Switzerland & 1998 & dep. & 1997 & 4 \\
\hline Iceland & 1997 & 1997 & 1999 & 4 & Turkey & $\mathrm{n} / \mathrm{a}$ & 2000 & 1924 & 3 \\
\hline Ireland & 1996 & 2002 & 1983 & 4 & UK & always & 1984 & 1984 & 5 \\
\hline Italy & 1998 & 1998 & 1997 & 4 & US & always & 1934 & 1890 & 6 \\
\hline
\end{tabular}

Data source: author compiled based on a variety of sources, including ITU-BDT online regulatory information database, countries' regulatory websites and mobile network operators' websites.

1. N/A: the events did not occur yet;

2. dep.: a separate regulator is subject to several other governmental bodies in its decision making.

3. Privatization is recorded for those where at least $50 \%$ of assets of state-owned companies have been sold to private sector; an independent regulator is recorded only if it is created backed by legislation and it claims to be independent of decision making.

\footnotetext{
${ }^{13}$ Also, see Appendix A for time series information of the actual number of MNOs by county from 1991 to 2006.
} 


\section{Econometric Methodology}

\subsection{Econometric Model}

Given the property of mobile network expansion, Griliches' (1957) logistic growth model, in which the technology diffusion conforms to an S-shaped (logistic) function, ${ }^{14}$ is used to develop the econometric system that incorporates the reform variables plus the consideration of possible endogeneity issues. Another advantage of using the growth model is that the demand and supply factors that may affect mobile network penetration can be simply included in one function. More specifically, let $M b p n_{i t}$ denote the number of people (per 100 inhabitants) that have adopted the mobile network services in the country $i$ at the time $t$. Let $N_{i}^{*}$ denote the total size of mobile network adopters (in percentages) in the country $i$ when the network expansion is completed. ${ }^{15}$ The mobile network expansion in the country $i$ at the time $t$ follows the logistic function, specified as:

$$
\operatorname{Mbpn}_{i t}=\frac{N_{i}^{*}}{1+\exp \left(-\left(\alpha_{i}+\beta^{\prime} x_{i t}+u_{i}+\varepsilon_{i t}\right)\right)}
$$

After a transformation and re-arrangements, it produces the following model for testing the reform effects:

$$
y_{i t}=\ln \left(\frac{M b p n_{i t}}{100-M b p n_{i t}}\right)=\alpha_{i}+\beta^{\prime} x_{i t}+u_{i}+\varepsilon_{i t}
$$

where the dependent variable $y_{i t}$ follows a logistic (normal) distribution, $\alpha_{i}$ is the country's individual specific effects, $x_{i t}$ is a vector of possible variables - describing the mobile reform environments and other demand or supply conditions in the country $i$ at the time $t$-determining the mobile network expansion in the country $i$ at the time $t, \beta$ is a vector of corresponding coefficients, $u_{i}$ is a country individual specific effects error, and $\varepsilon_{i t}$ is a normal model error term with white noise. ${ }^{16}$

\footnotetext{
${ }^{14}$ See, Mansfield (1961), for test and detailed explanation for why growth curve should conform to the logistic function.

${ }^{15} \mathrm{I}$ bound the upper limits of the expansion of mobile network services to be one mobile telephone per inhabitant, hence the ceiling of network expansion is assumed to be $100 \%$, same across countries, i.e. $N_{i}^{*}=100$. Since this assumption has been increasingly challenged given the fact that the real mobile penetration (i.e. the number of mobile subscribers per 100 inhabitants) has exceeded 100 in many countries (it has been seen that some people have two or more subscriptions with different MNOs), I further conduct several experiments with higher levels of the ceiling such as 150 or 200 . However, these trials did not affect much the model estimation results in both the values and significant levels of the estimated coefficients. It seems to be that bounding the mobile penetration between zero and 100 has already captured the most interesting story of mobile network expansion. Therefore, this study eventually keep the original assumption that $N_{i}^{*}=100$.

${ }^{16}$ White-noise means the model residual is completely random with three properties: zero mean, no autocorrelation and homoscedasticity.
} 
I further consider that there are two possible variables affecting mobile network expansion determined simultaneously within the model. One is the mobile services price which may be determined by the demand for mobile network services and by the mobile reforms, in particular, the competition (see equation (3)). The other is the mobile labour productivity that may also be determined by some reform variables (see equation (4)).

mobile_price ${ }_{i t}=\rho_{i}+\beta_{p}^{\prime} x_{p i t}+\eta_{i}+\omega_{i t}$,

mobile _ productivi ty ${ }_{i t}=\theta_{i}+\beta_{l p}^{\prime} x_{l p i t}+v_{i}+\vartheta_{i t}$,

where $x_{p i t}$ is a vector of explanatory variables for the mobile services price, and $x_{\text {lpit }}$ is a vector of explanatory variables for the mobile labour productivity. Hence, the equation (2) needs to be estimated with equations (3) and (4) simultaneously by using the two-stage least squares (2SLS) instrumental variable method, in which part of the explanatory variables may be pre-determined and all the parameters of the model are estimated jointly (see Berndt, et al., 1975; Hausman, 1975). These endogeneity issues are further tested by applying the Hausman specification test for panel instrumental model (Hausman, 1978; Hausman and Taylor, 1981). ${ }^{17}$

\subsection{Variables Description ${ }^{18}$}

As described previously, a set of dummy variables are included to test the six hypotheses regarding the reform effects on mobile network penetration, namely the privatization dummy ( $\left.P r v_{i t}\right)$, entry dummies (dumEntry2 $2_{i t}$ to dumEntry $7_{i t}$, and monopoly as base dummy), independent regulator dummy (Indep $p_{i t}$, and two interactions - privatization interacted with independent regulator $\left(i t c / n P_{i t}\right)$ and with the number of entrants (itcNoFP $i t)$, respectively.

In addition, I include some demand and supply factors that may affect mobile penetration: income level - measured by GDP per capita (GDPpcit), mobile price of 3-minute local call $\left(M b p_{i t}\right)$, fixed-line price of 3-minute local call $\left(F x p_{i t}\right)$, fixed-line penetration $\left(F x p n_{i t}\right)$, and mobile labour productivity $\left(M S p s_{i t}\right)$. Income level is usually expected to positively affect mobile penetration. While the mobile price is negatively

\footnotetext{
17 The Hausman specification test for panel instrumental estimator is based on $\mathrm{H}_{0}$ : no misspecification (panel fixed-effect estimator is efficient and preferred); $\mathrm{H}_{1}$ : misspecification (panel instrumental estimator is efficient and preferred). The test calculates the difference between estimates under two specifications. If the difference does not differ from zero, then $\mathrm{H}_{0}$ is accepted and, the instrumental approach is not necessary. If the difference differs from zero substantially, then $\mathrm{H}_{0}$ is rejected and the misspecification is apt to be serious, meaning the panel instrumental estimator is efficient and necessary.

${ }_{18}$ This section, here, only described variables used in equation (2), i.e. those affecting the mobile penetration. See Appendix $\mathrm{B}$ for a table summary of variables, where presents all variables in the system.
} 
correlated with the demand for mobile network services, the fixed-line price may have a positive or a negative effect depending on whether the fixed-mobile usages are substitutes or complements. The fixed-line penetration captures the size of the fixed network and again may have a positive or a negative effect depending on whether the fixed-mobile platforms are complements or substitutes. The last one captures the capacity of the mobile services supply and can have a positive effect on the mobile penetration.

Finally, I also include several other control variables to capture the features of countries' market conditions, that are, urbanization - measured by the urban population as a percentage of total population $\left(U b p r_{i t}\right)$, national population $\left(P_{o p} p_{i t}\right.$ and time trend $(t)$. National population and time trend are used to capture the national market size and the technological progress, respectively. Urbanization is usually believed to have a positive effect on mobile penetration; because (1) most countries have their mobile signals better covered in urban areas rather than in rural areas, and (2) people living in urban areas are more likely to use mobile services than those living in rural areas, owing to a relatively better income, standard of living and a higher propensity to adopt new technology.

\subsection{Model Approaches}

All variables, except for time trend and dummies, in the model system are in the natural logarithmic form. Hence, I have a log-linear and log-log specification for the model estimations. More specifically, the general econometric model (i.e. a 3equation system, combining equations (2), (3) and (4)) is approached by the following three model estimations: panel equation-by-equation fixedeffects ${ }^{19}$ estimation, panel fixed-effects instrumental estimation, and panel dynamic estimation. $^{20}$

\footnotetext{
${ }^{19}$ The fixed-effects estimation is commonly used for a panel analysis to control unobserved individual specific effects that may exist in the individual specific effects error, and in turn, can be highly correlated with the explanatory variables in the model (see Breusch, T.S. and A.R. Pagan, 1979; Hausman and Taylor, 1981). I further apply the Hausman test for fixedeffects model and Breusch-Pagen test for unobserved heterogeneity in the individual specific effects error to confirm that the fixed-effects estimation is more efficient and should be preferred.

The Hausman test for fixed-effect model is based on $\mathrm{H}_{0}$ : individual effects error $u_{i}$ uncorrelated with independent variables (random-effects estimator is efficient and preferred); $\mathrm{H}_{1}$ : individual effect error $u_{i}$ correlated with at least one or more independent variables (fixed-effects estimator is preferred). This test focuses on the correlation between individual effect error $u_{i}$ and independent variables, which differs from specification test for instrumental estimator that focus on the autocorrelation between model errors, $u_{i} \& \varepsilon_{i t}$ and endogenous explanatory variables.

The Breusch-Pagen test $(1979,1980)$ is based on $H_{0}: \sigma_{u}^{2}=0$ (no unobserved individual heterogeneity); $H_{1}: \sigma_{u}^{2} \succ 0$ (unobserved heterogeneity in individual effects error). The variance of the panel estimator errors consists of two parts, variance of normal model error and variance of individual effects error, i.e. $\operatorname{Var}\left(e_{i t}\right)=\sigma_{e}^{2}=\sigma_{\varepsilon}^{2}+x_{i t}^{2} \sigma_{u}^{2}$. The Breusch-Pagan
} 
- Panel equation-by-equation fixed-effects estimation

I start to estimate a simple Model (1) including the individual reform variables and two control variables (income level and time trend) and using the quadratic form of the number of MNOs to have a first look at the reform effects in general, and the non-linear new entry effects in particular.

$y_{i t}=\alpha_{1 i}+\beta_{11} N o F+\beta_{12} s_{\text {SNOF }}+\beta_{13} \operatorname{prv}_{i t}+\beta_{14} \operatorname{Indep}_{i t}+\beta_{15} \ln G D P p c_{i t}+\beta_{16} t+u_{i}+\varepsilon_{i t}$

And then, I estimate the Model (2) by replacing the quadratic form of the number of MNOs in the Model (1) with a set of entry dummies to look at more detailed new entry effects, specified as

$y_{i t}=\alpha_{2 i}+\beta_{21 j} D_{j}(\text { entry })_{i t}+\beta_{22} \operatorname{prv}_{i t}+\beta_{23}$ Indep $_{i t}+\beta_{24} \ln G D P p c_{i t}+\beta_{25} t+u_{i}+\varepsilon_{i t}$

After that, I estimate an expanded Model (3) by including two interactive terms (i.e. privatization interacted with the independent regulator and privatization interacted with the number of entrants) and by taking other exogenous control variables on broad, specified as

$$
\begin{aligned}
y_{i t}= & \alpha_{3 i}+\beta_{31 j} D_{j}(\text { entry })_{i t}+\beta_{32} \text { prv }_{i t}+\beta_{33} \operatorname{Indep}_{i t}+\beta_{34} i t c I n P_{i t}+\beta_{35} i t c N o F P_{i t}+\beta_{36} \ln F_{x p n_{i t}} \\
& +\beta_{37} \ln F x p_{i t}+\beta_{38} \ln G D P p c_{i t}+\beta_{39} \ln U b p r_{i t}+\beta_{391} \ln P_{i t}+\beta_{392} t+u_{i}+\varepsilon_{i t}
\end{aligned}
$$

Note that two endogenous explanatory variables (mobile price and labour productivity) are not included in the mobile penetration model at this stage. To deal with the endogenous problems, it requires estimating a structural model using the 2SLS instrumental variable method (Hausman, 1978; Hausman and Taylor, 1981). Before doing so, I estimate the mobile-price equation and the productivity equation, respectively, to see whether those two variables are determined within the mobile penetration model. That is, to estimate equations (3) and (4) specified as $\ln M b p_{i t}=\rho_{i}+\beta_{51} N o F_{i t}+\beta_{52} \operatorname{prv}_{i t}+\beta_{53}$ Indep $_{i t}+\beta_{54} y_{i t}+\beta_{55} \ln G D P p c_{i t}+\beta_{56} \ln C p u_{i t}+\beta_{57} \ln M b p_{-} e e_{i t-1}+\eta_{i}+\omega_{i t}$
$\ln M \operatorname{Sps}_{i t}=\theta_{i}+\beta_{61 j} D_{j}\left(\right.$ entry $_{i t}+\beta_{62} \operatorname{prv}_{i t}+\beta_{63}$ Indep $_{i t}+\beta_{64} \ln G D P p c_{i t}+\beta_{65} \ln T I r_{i t}+\beta_{66} t+v_{i}+v_{i t}$

test focuses on the latter part, the variance of individual effects error, i.e. $\operatorname{Var}\left(u_{i}\right)=\sigma_{u}^{2}$. And, for panel estimators, it is used to be conducted following the Hausman test for random-effect vs. fixed-effect panel model. If the Ho is false, $x_{i t}^{2} \sigma_{u}^{2}$ is impossible to be a constant value and, in turn, $\operatorname{Var}\left(e_{i t}\right)=\sigma_{e}^{2}=\sigma_{\varepsilon}^{2}+x_{i t}^{2} \sigma_{u}^{2}$ is no longer constant, even though $\varepsilon_{i t}$ is i.i.d. $\left(0, \sigma_{\varepsilon}^{2}\right)$ (but, in fact, under individual specific effects, $\varepsilon_{i t} \sim\left(0, \sigma_{\varepsilon_{i t}}^{2}\right)$ ). And, in effect, $e_{i t}$ is no longer $\sim\left(0, \sigma_{e}^{2}\right)$, but $e_{i t} \sim\left(0, \sigma_{i t}^{2}\right)$. Hence, if the Breush-Pagen test rejects $H_{0}: \sigma_{u}^{2}=0$, then it suggests that the model is heteroscedasticity.

${ }^{20} \mathrm{I}$ also report estimation results with heteroscedastic corrected standard errors. 
- Panel fixed-effects instrumental estimation

I now further expand the model by including mobile-price and productivity variables, and estimate the Model (4) (specified below) with the specified equations (3) and (4) simultaneously by using the two-stage least squares (2SLS) instrumental variable method, in which the mobile price and productivity variables can be predetermined and all the parameters of the model are estimated jointly. ${ }^{21}$

$$
\begin{aligned}
y_{i t}= & \alpha_{4 i}+\beta_{41 j} D_{j}\left(\text { entry }_{i t}+\beta_{42} \text { prv }_{i t}+\beta_{43} \text { Indep }_{i t}+\beta_{44} i t c I n P_{i t}+\beta_{45} i t c N o F P_{i t}+\beta_{46} \ln F x p n_{i t}+\beta_{47} \ln F x p_{i t}\right. \\
& +\beta_{48} \ln G D P p c_{i t}+\beta_{49} \ln U b p r_{i t}+\beta_{491} \ln \operatorname{Pop}_{i t}+\beta_{492} t+\beta_{493} \ln M b p_{i t}+\beta_{494} \ln M S p s_{i t}+u_{i}+\varepsilon_{i t}
\end{aligned}
$$

- Panel dynamic estimation

Finally, I employ Arellano-Bond dynamic panel estimation ${ }^{22}$ for the Model (3) (i.e. estimating data in the $1^{\text {st }}$ difference form) to test how the changing policies (e.g. from absence to presence of an independent regulator, introducing a new entrant, and transforming ownership from state to private) affect the growth of mobile penetration beyond the impacts derived from the positive network effects.

In summary, I firstly use panel fixed-effects equation-by-equation estimation to test the impacts of these three reform dimensions and their interactive effects on mobile network penetration by taking on board other control variables that may have determined the mobile penetration, and also, to test the effects of these reforms on mobile services price and labour productivity to address the possible endogeneity issues. Secondly, I apply panel fixed-effects instrumental estimation under 2SLS technique to deal with the potential endogenous problems. Finally, I employ Arellano-Bond dynamic panel estimation (i.e. using data in the $1^{\text {st }}$ difference form) to shed light on how the changing regulatory policies (e.g. from absence to presence of a separate regulator, licensing a new entry, and transforming a state ownership into a private ownership) affect the pace of mobile network expansion beyond the impacts derived from the positive network effects during the period I study.

\footnotetext{
${ }^{21}$ All exogenous explanatory variables are used as instruments in estimating the Model (4). The model is clearly overidentified as the number of excluded exogenous variables (i.e. InCpu $u_{i t}, \operatorname{InMbp}_{i t-1}$ and $I n T I r_{i t}$ ) exceeds the number of included endogenous variable in the right-hand-side of the Model (4).

${ }^{22}$ See, Arellano and Bond, 1991; Blundell and Bond, 1998) and Bond, 2002 for reference.
} 


\section{Results ${ }^{23}$}

Tables III, IV and V present the results of estimating models (1)-(4) and equations (3) \& (4) above with three different approaches. The results are, in general, consistent with findings of the existing literature. Introducing new entry is, on balance, associated with increased mobile network penetration, labour productivity and lower service prices. Privatization by itself, meanwhile, is associated with few benefits. Even combining with certain degrees of competition, the effect of privatization is still less clear. However, with the complement of an independent regulator, privatization is associated with increased mobile penetration. An independent regulator, per se, is also associated with increased mobile penetration and labour productivity. Below I first discuss in detail the results of each of the three reforms, and then I discuss the effects of other control variables.

\subsection{New Entry Effects}

The new entry effects on the mobile network penetration, in general, follow an inverted U-shape. That can be seen from the estimation results of Model (1) where the linear term of the number of MNOs is associated with a positive coefficient and its squared term is associated with a negative coefficient, and both coefficients are significant at $1 \%$ level. More specifically, the third entry seems to be associated with the highest mobile penetration and the fastest network expansion. These observations are suggested by the results of both panel equation-by-equation estimations (Models (2) and (3)) and panel dynamic estimations (Table IV) - the coefficients of the third entry dummy are always associated with the highest and most significant values across these estimations. After further joint significance tests, using likelihood ratios reported by the FGLS procedure of Model (3), I find evidence that the third entry is associated with significantly higher mobile penetration than the second entry, ceteris paribus; meanwhile entries between the third and the fifth bring similar benefits to the mobile penetration, ceteris paribus. ${ }^{24}$

\footnotetext{
${ }^{23}$ Significance of all explanatory variables are observed at three levels: ${ }^{* * *},{ }^{* *}$ and ${ }^{*}$, meaning strong significance at $1 \%$ level, with one-tailed $p$-value $<0.01$, significance at $5 \%$ level, with one-tailed $p$-value $<0.05$, and mild significance at $10 \%$ level, with one-tailed $p$-value $<0.1$, respectively.

${ }^{24}$ Panel estimators report three $R^{2} s$ that are estimated based on within effects, between effects and overall effects, respectively. Those panel estimated $R^{2} s$ differ from the $R^{2}$ reported by OLS that can be used in the formula of F-test to work out F-statistics used to compare with the critical value of F-statistics for joint significance test under OLS estimations. Therefore, the formula of F-test for joint significance is biased under panel estimations. But, the formula of Log-likelihood: $L R=2 \times\left(L_{u}-L_{r}\right)$ is appropriate, and the critical values of $\chi^{2}$ are used as the reference for those tests, instead of using critical values of $F$-statistics.
} 
The new entry effects start to diminish and even become negative after the fifth entry.

In addition, the new entry effects are also significant at some levels in equations (3) and (4). In the mobile-price equation (3), the number of entries is associated with a strong significant and negative coefficient. And in the productivity equation (4), the second and the third entries are associated with significant labour productivity improvements. More interestingly, the seventh entry is significantly negatively correlated with labour productivity, which consists with the diminishing effects of new entries after the fifth on the mobile penetration.

\subsection{Privatization Effects}

The effects of privatization are fairly complex across models' estimations. The results of estimating equations (3) and (4) show that privatization has no significant impact on mobile price and labour productivity. Although, in the simplest models (1) and (2), there are some positive effects associated with privatization, these effects become much less significant when heteroscedastic corrected standard errors are reported. Privatization interacted with independent regulator, however, is positively correlated with both the mobile network penetration (see Models (3) and (4)) and expansion (see Table IV: dynamic estimation). In contrast, the interaction of privatization and the number of entrants is associated with insignificant coefficients in the models (3) and (4) (it is thus removed from the models), meaning that to benefit mobile penetration, it is not necessary for the MNOs to be privatized. Especially, the dynamic estimation results show that privatization by itself has a large significant negative impact on the network expansion (i.e. $-0.2320^{*}$ for the short term, and $-0.9307^{\star}$ for the long term), which can not be offset even by the positive effect of privatization interacted with the average number of entrants (i.e. $0.0638 \times 3=0.1914$ for the short-term, and $0.2558 \times 3=0.7674$ for the long-term). This result further suggests that privatization, on average, hampers the mobile network expansion in both the short-term and long-term. Nevertheless, the negative effect of privatization can be further offset if adding the effect of privatization interacted with

\footnotetext{
Two joint significance tests are operated here. One is to test the different effects between the second entry and the third entry. The other is to test the different effects between the third entry, the fourth entry and the fifth entry.

The first test is under $\mathrm{H}_{0}: \beta_{\text {dumEentry } 2}=\beta_{\text {dumEntry } 3}$, I have $L R=2 \times(-465.3851-(-471.5539))=12.34 \succ \chi_{0.05}^{2}(1)=3.84$, and hence reject the $\mathrm{H}_{0}$. And, the second test is under $\mathrm{H}_{0}: \beta_{\text {dumEentry3 }}=\beta_{\text {dumEntry } 4}=\beta_{\text {dumEntry5 }}$, I have $L R=2 \times(-465.3851-(-465.775))=0.78 \prec \chi_{0.05}^{2}(2)=5.99$, hence accept the $\mathrm{H}_{0}$.
} 
independent regulator, which implies the importance of independent industry regulator, in particular, in the privatized market.

\subsection{Independent Regulator Effects}

An independent regulator, per se, in general, is significantly and positively correlated with mobile penetration across most models estimations, except in Model (4) that includes two endogenous explanatory variables - mobile price and labour productivity. That is mainly because the independent regulator also has significant positive impacts on labour productivity (equation (4)), and hence, when they are both in the same model simultaneously, the effects of the independent regulator on mobile penetration are mediated by the labour productivity variable. In other words, the significant positive effects of labour productivity on mobile penetration capture the effects of the independent regulator, per se, in Model (4). Similarly, the significant negative effects of mobile price and the significant positive effects of labour productivity on mobile penetration also capture parts of the new entry effects (i.e. lower the values of the coefficients associated with entry dummy variables) in Model (4), since the variables indicating new entries are significantly correlated with both mobile price and labour productivity in estimating equations (3) and (4), respectively. The effects of independent regulator interacted with privatization, however, are still significant and positive in Model (4), which suggests that the facilitating effects of an independent regulator in a privatized market are of utmost importance, compared to its direct effects on mobile penetration. This facilitating effect is further confirmed by the dynamic estimation results that independent regulator interacted with privatization is significantly and positively correlated with the pace of network expansion.

\subsection{Effects of Other Control Variables}

As expected, income level - GDP per capita - is positively correlated with mobile penetration; whereas it is not significant to the pace of network expansion (see dynamic estimation). Population is negatively correlated with mobile penetration, and the urban population ratio is positively correlated with mobile penetration. In addition, the coefficients associated with fixed-line price are positive and significant across models, which confirm the substitutive relationship between fixed-mobile usages. The signs of the coefficients of fixed-line penetration, however, are mixed 
across models. Finally, time trend is positively correlated with both mobile penetration and the pace of network expansion.

\section{Conclusions and Remarks}

This study explores the impacts of privatization, new entry and independent industry regulator on mobile network penetration and expansion by various econometric approaches, using panel data for 30 national mobile markets (i.e. 29 OECD countries and China) over the time period 1991-2006. On balancing all model estimation results, I fully accept Hypotheses 1, 5 and 6, and partially accept Hypothesis 2, but reject Hypotheses 3 and 4. Thus, I conclude this study with the following primary insights.

First, the new entry effects on mobile penetration follow an inverted U-shape. Specifically, the third-to-fifth entries are jointly associated with the highest penetration (the effects start to decline after the fifth entry), and the third entry is also associated with the fastest network expansion. This result not only confirms the previous empirical findings that competition is associated with improved telecom performances (Hypothesis 1), but also originally reveals that duopoly competition is not sufficient for better mobile network development and, on average, three-to-fivefirm oligopolistic market competition appears to work better for the mobile network markets (Hypothesis 2). ${ }^{25}$ Moreover, the diminishing effects of entrants after the fifth suggests that too many entrants can eventually exert negative influence on the network expansion, as over-intense competition may result in fewer incentives to improve service quality as the services become less profitable.

Second, privatization alone yields few benefits to mobile penetration. Especially, dynamic estimation results imply that even with certain degrees of competition, privatization is, on average, harmful to mobile network expansion, unless there is an independent industry regulator. This result, on one hand, is consistent with findings of the existing literature that privatization alone may not generate telecom improvements. It needs to be complemented by effective regulatory framework

\footnotetext{
${ }^{25}$ Since the new entry effects start to diminish after the fifth entrant, the Hypothesis 2 is partially true. This result is thus more meaningful, as it provides important references to the number of MNOs should be licensed.
} 
(Hypothesis 6). On the other hand, it challenges the conventional theory that private ownership is superior to public ownership when competition in the product/service market is effective (Vickers and Yarrow, 1988). Therefore, this result, by rejecting both Hypotheses 3 and 4, further emphasizes that to benefit mobile network penetration and expansion, it is not necessary for mobile network operators to be privatized.

Third, independent regulator, per se, is positively correlated with mobile penetration; and the role of an independent regulator is particularly crucial in the privatized mobile markets. This result meets Hypotheses 5 and 6, and in turn, provides evidence that the independent regulator is not only a determinant institutional element of good regulatory governance, but also has explicit effects on certain performance measures, such as mobile network penetration and expansion.

Finally, this study also finds that mobile service price and labour productivity partially mediate the effects of regulatory reforms, in particular, of new entries and an independent regulator, suggesting that those reforms affect network penetration and expansion partially through their effects on price reduction and labour productivity improvement.

\subsection{Policy Implications}

Although many studies along with this one have suggested that privatization alone may not necessarily yield performance improvements, there is still a trend towards massive privatization around the world, in particular, in the developing country. Accordingly, building up a formal independent regulatory authority for individual sectors should be recommended, in particular, for countries which have already privatized their markets or intend to privatize their markets. In addition, we should notice that the real driving power for vigorous market dynamics is sufficient and effective competition. Therefore, it is imperative for reformers to foster an effective competitive environment (i.e. encouraging new entries into the market) rather than rushing into massive privatization. More importantly, only an appropriate competition level (neither inadequate nor over-competitive) is beneficial to economic performance and efficiency. Therefore, an apposite range of the number 


\section{of entries into a market should be carefully examined based on different and} specific political and economic conditions.

\section{Table 3: Estimations Results by Panel Equation-by-Equation and Panel Instrumental Approaches}

Dependent variable: $y_{i t}=\ln \left(M b p n_{i t} /\left(100-M b p n_{i t}\right)\right)$

\begin{tabular}{|c|c|c|c|c|c|c|c|c|}
\hline \multicolumn{3}{|c|}{ Model (1) } & \multicolumn{2}{|c|}{ Model (2) } & \multicolumn{2}{|c|}{ Model (3) } & \multicolumn{2}{|c|}{ Model $(4)^{26}$} \\
\hline \multicolumn{9}{|c|}{ New entry effects: } \\
\hline NoF & $0.9749^{\star \star \star}$ & $0.8800^{* * *}$ & & & & & & \\
\hline sqNoF & $\begin{array}{l}6.38 \\
-0.1367^{\star * *} \\
-6.64\end{array}$ & $\begin{array}{l}6.24 \\
-0.1404^{\star * *} \\
-7.73\end{array}$ & & & & & & \\
\hline \multicolumn{2}{|l|}{ dumEntry2 } & & $\begin{array}{l}0.4765^{* * *} \\
3.87\end{array}$ & $\begin{array}{l}0.3718^{* * *} \\
2.76\end{array}$ & $\begin{array}{l}0.5962^{* * *} \\
5.07\end{array}$ & $\begin{array}{l}0.5977^{\star * *} \\
5.63\end{array}$ & $\begin{array}{l}0.3591^{\star * *} \\
3.32\end{array}$ & $\begin{array}{l}0.1919^{\star *} \\
1.83\end{array}$ \\
\hline \multirow[t]{2}{*}{ dumEntry3 } & & & $1.0231^{* * *}$ & $0.8150^{* * *}$ & $1.1265^{\star * *}$ & $1.0068^{* * *}$ & $0.7066^{\star * *}$ & $0.5768^{* * *}$ \\
\hline & & & 5.93 & 4.61 & 7.01 & 7.08 & 4.77 & 3.84 \\
\hline \multirow{2}{*}{ dumEntry4 } & & & $0.6041^{* * *}$ & $0.3650^{* *}$ & $0.8153^{* \star *}$ & $0.9571^{* * *}$ & $0.5937^{* * *}$ & $0.3370^{* *}$ \\
\hline & & & 2.80 & 1.90 & 3.88 & 5.91 & 3.16 & 2.24 \\
\hline \multirow[t]{2}{*}{ dumEntry5 } & & & $0.7483^{* * *}$ & $0.4601^{* *}$ & $1.0582^{* * *}$ & $1.1085^{\star * *}$ & $0.9172^{\star * *}$ & $0.7780^{* * *}$ \\
\hline & & & 3.07 & 1.95 & 4.59 & 5.62 & 4.48 & 4.60 \\
\hline \multirow[t]{2}{*}{ dumEntry6 } & & & -0.4383 & $-1.1995^{\star \star \star}$ & 0.2465 & 0.3631 & 0.1881 & 0.1518 \\
\hline & & & -1.11 & -3.35 & 0.67 & 1.13 & 0.58 & 0.47 \\
\hline \multirow[t]{2}{*}{ dumEntry7 } & & & $-0.5623^{*}$ & $-1.2056^{\star \star \star}$ & 0.1008 & 0.1611 & -0.0309 & -0.1630 \\
\hline & & & -1.30 & -4.34 & 0.25 & 0.51 & -0.09 & -0.57 \\
\hline \multicolumn{9}{|c|}{ Privatization effects: } \\
\hline Prv & $\begin{array}{l}0.5302^{\star \star *} \\
4.39\end{array}$ & $\begin{array}{l}0.1382 \\
1.23\end{array}$ & $\begin{array}{l}0.5466^{\star * *} \\
4.56\end{array}$ & $\begin{array}{l}0.1738^{*} \\
1.54\end{array}$ & $\begin{array}{l}0.1806 \\
1.25\end{array}$ & $\begin{array}{l}0.1944^{* *} \\
1.80\end{array}$ & $\begin{array}{l}0.0901 \\
0.70\end{array}$ & $\begin{array}{l}0.0213 \\
0.23\end{array}$ \\
\hline \multicolumn{9}{|c|}{ Independent regulator effects: } \\
\hline \multirow[t]{2}{*}{ Indep } & $0.3891^{\star \star \star}$ & $0.4015^{\star \star \star}$ & $0.3283^{* * *}$ & $0.3973^{\star * *}$ & $0.2278^{*}$ & $0.3400^{\star \star \star}$ & 0.0926 & 0.0679 \\
\hline & 3.26 & 4.04 & 2.77 & 3.99 & 1.55 & 2.90 & 0.71 & 0.70 \\
\hline \multirow[t]{2}{*}{ itclnP } & & & & & $0.4005^{* *}$ & 0.1172 & $0.3548^{* *}$ & $0.4241^{* \star *}$ \\
\hline & & & & & 2.24 & 0.87 & 2.23 & 3.50 \\
\hline \multicolumn{9}{|c|}{ Other control effects: } \\
\hline \multirow{2}{*}{ InGDPpc } & $1.9950^{\star \star \star}$ & $1.6992^{\star \star \star}$ & $1.8041^{\star * *}$ & $1.6787^{\star \star \star}$ & 0.0378 & $0.5975^{\star \star *}$ & $1.4049^{\star \star \star}$ & 0.5405 \\
\hline & 4.34 & 20.29 & 3.89 & 19.38 & 0.06 & 4.55 & 2.63 & 1.06 \\
\hline \multirow[t]{2}{*}{ time trend } & $0.3657^{* * *}$ & $0.4216^{* * *}$ & $0.3770^{\star * *}$ & $0.4153^{\star \star *}$ & $0.4675^{* * *}$ & $0.3938^{* * *}$ & $0.2609^{* * *}$ & $0.1977^{\star \star * *}$ \\
\hline & 13.16 & 30.28 & 13.50 & 30.55 & 15.18 & 35.78 & 7.75 & 2.96 \\
\hline InFxpn & & & & & $\begin{array}{l}0.8637^{\star \star *} \\
4.02\end{array}$ & $\begin{array}{l}0.8328^{\star * *} \\
7.66\end{array}$ & $\begin{array}{l}-0.3912^{* *} \\
-1.73\end{array}$ & $\begin{array}{l}-0.1211 \\
-0.32\end{array}$ \\
\hline \multirow[t]{2}{*}{$\operatorname{InFxp}$} & & & & & $7.0406^{\text {*** }}$ & $1.3573^{\star *}$ & $5.8863^{\star \star *}$ & $3.2176^{\star \star *}$ \\
\hline & & & & & 4.43 & 2.05 & 4.11 & 2.47 \\
\hline \multirow[t]{2}{*}{ InUbpr } & & & & & 1.0492 & $-0.9704^{\star * \star}$ & $2.8483^{\star *}$ & $2.3552^{*}$ \\
\hline & & & & & 0.55 & -4.72 & 1.67 & 1.45 \\
\hline InPop & & & & & $-9.3651^{* * *}$ & $-0.2147^{* * *}$ & $-7.4927^{\star \star \star}$ & $-4.7131^{\star * *}$ \\
\hline & & & & & -5.44 & -7.99 & -4.87 & -3.58 \\
\hline InMbp & & & & & & & $-0.2506^{\star}$ & $-0.4475^{\star \star}$ \\
\hline & & & & & & & -1.62 & -2.01 \\
\hline InMSps & & & & & & & $0.5011^{\star * *}$ & $0.6651^{\star \star \star}$ \\
\hline & & & & & & & 10.10 & 4.25 \\
\hline & $n=447$ & $\mathrm{n}=447$ & $\mathrm{n}=447$ & $\mathrm{n}=447$ & $\mathrm{n}=447$ & $\begin{array}{l}\mathrm{n}=447 \\
\text { Wald }\end{array}$ & $n=447$ & $n=383$ \\
\hline & $\begin{array}{l}\mathrm{R}^{2}=0.9311 \\
\text { (within) }\end{array}$ & $\begin{array}{l}\text { Wald } \\
\text { Chi2 }(6)= \\
4005.76\end{array}$ & $\begin{array}{l}\mathrm{R}^{2}=0.9338 \\
\text { (within) }\end{array}$ & $\begin{array}{l}\text { Wald } \\
\text { Chi2 } 2(10)= \\
4177.68\end{array}$ & $\begin{array}{l}\mathrm{R}^{2}= \\
0.9468 \\
\text { (within) }\end{array}$ & $\begin{array}{l}\text { Chi2 }(15)= \\
7412.59 \\
\text { Log likelihood } \\
=-465.3851\end{array}$ & $\begin{array}{l}\mathrm{R}^{2}=0.9583 \\
\text { (within) }\end{array}$ & $\begin{array}{l}\mathrm{R}^{2}=0.9759 \\
\text { (within) }\end{array}$ \\
\hline $\begin{array}{l}\text { Het- } \\
\text { corrected } \\
\text { Std.Err. }\end{array}$ & $\mathrm{FE}$ & Yes & FE & Yes & FE & Yes FGLS & $\mathrm{FE}$ & FE \\
\hline $\begin{array}{l}\text { Models: (1) } \\
\text { with a set } \\
\text { standard er } \\
\text { exogenous } \\
\text { ratio that us } \\
\text { instruments } \\
\text { dumEntry4 } \\
\text { In all mode } \\
\text { type. }\end{array}$ & $\begin{array}{l}\text { 1odel with qua } \\
\text { entry dummie } \\
\text { rs are reporte } \\
\text { ontrol variable } \\
\text { d for later joint } \\
\text { or mobile pric } \\
\text { umEntry5 dum } \\
{ }^{* * *} \text { significant }\end{array}$ & $\begin{array}{l}\text { tic form of } t \\
\text { using mono } \\
\text { the latter } \\
\text { and the latte } \\
\text { anificance te } \\
\text { and product } \\
\text { try } 6 \text { dumEn } \\
1 \% ;{ }^{* *} \text { signi }\end{array}$ & $\begin{array}{l}\text { רumber of MN } \\
\text { as base case } \\
\text { (3) model inc } \\
\text { he uses the F } \\
\text { on differences } \\
\text {; and the latte } \\
\text { Prv Indep itclr } \\
\text { t at } 5 \% \text {; }{ }^{*} \text { sign }\end{array}$ & $\begin{array}{l}\text { and the latt } \\
\text { testing spec } \\
\text { ing the inter } \\
\text { s procedure } \\
\text { tween entrie } \\
\text { an instrum } \\
\text { InFxp InFxp } \\
\text { ant at } 10 \% \text {; }\end{array}$ & $\begin{array}{l}\text { ne reports he } \\
\text { ffects of eac } \\
\text { e term of pri } \\
\text { orting heteros } \\
\text { ) model inclu } \\
\text { l estimation } \\
\text { bpr InPop t N } \\
\text { tistics / z-sta }\end{array}$ & $\begin{array}{l}\text { roscedastic corr } \\
\text { new entry; and } \\
\text { tization and the } \\
\text { edastic correcte } \\
\text { ng endogenous } \\
\text { th instruments: } \\
\text { FInCpu InL } 1 M b r \\
\text { stics are reporte }\end{array}$ & $\begin{array}{l}\text { ted standard } \\
\text { gain heterosce } \\
\text { dependent res } \\
\text { standard error } \\
\text { riables, the fo } \\
\text { GDPpc dumE } \\
\text { nTIr. } \\
\text { below each c }\end{array}$ & $\begin{array}{l}\text { rors; (2) model } \\
\text { astic corrected } \\
\text { lator and other } \\
\text { and, likelihood } \\
\text { her one with no } \\
\text { ry2 dumEntry3 } \\
\text { fficient in italic }\end{array}$ \\
\hline
\end{tabular}

\footnotetext{
${ }^{26}$ The Hausman specification test result is in favour of the panel fixed-effects instrumental estimation, with $\chi_{0.05}^{2}(17)=2989.33$ and $p$-value $=0.0000$.
} 
Table 4: Panel Dynamic Estimation Results

Dependent variable: D. $y_{\text {it }}$

\begin{tabular}{|c|c|c|c|}
\hline & Short-run effects & $\bar{z}$ & Long-run effects \\
\hline \multicolumn{4}{|l|}{ Network effects: } \\
\hline LD.y & $0.7507^{\star \star \star}$ & 12.45 & ---- \\
\hline \multicolumn{4}{|c|}{ New entry effects: } \\
\hline D.dumEntry2 & $0.2598^{\star \star \star}$ & 3.56 & $1.0420^{\star \star \star}$ \\
\hline D.dumEntry3 & $0.3716^{\star \star \star}$ & 3.60 & $1.4905^{\star \star \star}$ \\
\hline D.dumEntry4 & $0.2237^{\star \star}$ & 1.66 & $0.8973^{\star \star}$ \\
\hline D.dumEntry5 & 0.1752 & 0.89 & 0.7028 \\
\hline D.dumEntry6 & 0.0260 & 0.10 & 0.1042 \\
\hline D.dumEntry7 & -0.0573 & -0.16 & -0.2298 \\
\hline \multicolumn{4}{|c|}{ Privatization effects: } \\
\hline D.Prv & $-0.2320^{*}$ & -1.96 & $-0.9307^{*}$ \\
\hline D.itcNoFP & $0.0638^{*}$ & 1.50 & $0.2558^{*}$ \\
\hline \multicolumn{4}{|c|}{ Independent regulator effects: } \\
\hline D.Indep & -0.0038 & -0.04 & -0.0154 \\
\hline D.itclnP & $0.1464^{*}$ & 1.55 & $0.5872^{*}$ \\
\hline \multicolumn{4}{|c|}{ Other control effects: } \\
\hline D.InFxpn & 0.2259 & 0.73 & 0.9063 \\
\hline D.InFxp & -0.7374 & -0.57 & -2.9580 \\
\hline D.InGDPpc & -0.1550 & -0.22 & -0.6219 \\
\hline D.InUbpr & -0.6570 & -0.24 & -2.6353 \\
\hline D.InPop & -2.3380 & -1.01 & -9.3783 \\
\hline D.year & $0.1243^{\star \star \star}$ & 2.44 & $0.4985^{\star * *}$ \\
\hline Robust Std. Err. & \multicolumn{3}{|c|}{$\begin{array}{l}n=321 \\
\text { Wald chi2(19) = } 29877.25 \\
\text { Yes }\end{array}$} \\
\hline
\end{tabular}

Arellano-Bond test that average autocovariance in residuals of order 1 is 0 :

HO: no autocorrelation $z=-2.48 \operatorname{Pr}>z=0.0132$

Arellano-Bond test that average autocovariance in residuals of order 2 is 0 :

HO: no autocorrelation $z=-2.33 \operatorname{Pr}>z=0.0197$

T-statistics / z-statistics are reported below each coefficient in italic type.

*** significant at $1 \%$; ${ }^{* *}$ significant at $5 \%$; ${ }^{*}$ significant at $10 \%$

The long-run effects are obtained by removing subscript $t$ from the model, and then, all coefficients are divided by (10.7507).

Table 5: Reform Effects on Mobile Price and Labour Productivity

\begin{tabular}{|c|c|c|}
\hline Variable & Eq. (3): Mobile price & Eq. (4): Mobile labour productivity \\
\hline$\overline{\mathrm{NoF}}$ & $\begin{array}{l}-0.0290^{\star \star \star} \\
-2.42\end{array}$ & \\
\hline dumNoF2 & & $\begin{array}{l}0.5150^{\star * \star} \\
4.29\end{array}$ \\
\hline dumNoF3 & & $\begin{array}{l}0.4888^{\star * *} \\
2.82\end{array}$ \\
\hline dumNoF4 & & $\begin{array}{l}0.0861 \\
0.40\end{array}$ \\
\hline dumNoF5 & & $\begin{array}{l}-0.0728 \\
-0.28\end{array}$ \\
\hline dumNoF6 & & $\begin{array}{l}-0.0970 \\
-0.18\end{array}$ \\
\hline dumNoF7 & & $\begin{array}{l}-1.0077^{\text {***}} \\
-2.35\end{array}$ \\
\hline Prv & $\begin{array}{l}-0.0152 \\
-0.54\end{array}$ & $\begin{array}{l}0.0701 \\
0.61\end{array}$ \\
\hline Indep & $\begin{array}{l}0.0128 \\
0.44\end{array}$ & $\begin{array}{l}0.2539^{* *} \\
2.18\end{array}$ \\
\hline InGDPpc & $\begin{array}{l}0.2240^{* *} \\
2.20\end{array}$ & $\begin{array}{l}1.6020^{* * *} \\
3.38\end{array}$ \\
\hline InL1Mbp_ee & $\begin{array}{l}0.5298^{\star * *} \\
12.86\end{array}$ & \\
\hline y & $\begin{array}{l}-0.0393^{\star * *} \\
-3.79\end{array}$ & \\
\hline InCpu & $\begin{array}{l}0.0343^{\star *} \\
1.76\end{array}$ & \\
\hline InTIr & & $\begin{array}{l}0.4828^{* * *} \\
5.51\end{array}$ \\
\hline time trend & & $\begin{array}{l}0.3374^{\star \star *} \\
11.88\end{array}$ \\
\hline & $\begin{array}{l}\mathrm{n}=383 \\
\mathrm{R}-\mathrm{sq}=0.5159 \text { (within) } \\
\text { Fixed-effect }\end{array}$ & $\begin{array}{l}\mathrm{n}=386 \\
\mathrm{R}-\mathrm{sq}=0.8939 \text { (within) } \\
\text { Fixed-effect }\end{array}$ \\
\hline
\end{tabular}

T-statistics / z-statistics are reported below each coefficient in italic type.

${ }^{* * *}$ significant at $1 \%$; ${ }^{* *}$ significant at $5 \%$; *significant at $10 \%$. 


\section{References}

Arellano, M. and S. Bond (1991), "Some Tests of Specification for Panel Data: Monte Carlo Evidence and an Application to Employment Equations", Review of Economic Studies, 58(2): 277-297.

Berndt, E.K., Hall, B.H., Hall, R.E. and J.A. Hausman (1975), "Estimation and inference in nonlinear structural models", Annals of Economic and Social Measurement, 3/4: 653-665.

Breusch, T.S. and A.R. Pagan (1979), A Simple Test for Heteroscedasticity and Random Coefficient Variation, Econometrica, 47(5): 1287-1294.

Breusch, T.S. and A.R. Pagan (1980), "The Lagrange Multiplier Test and its Applications to Model Specification in Econometrics", Econometrics Issue, The Review of Economic Studies, 47(1): 239-253.

Blundell, R. and S. Bond (1998), "Initial conditions and moment restrictions in dynamic panel data models," Journal of Econometrics, 87(1): 115-43.

Bond, S. (2002), "Dynamic panel data models: A guide to micro data methods and practice", Working Paper 09/02, Institute for Fiscal Studies, London.

Boylaud, O. and G. Nicoletti (2001), "Regulation, Market Structure and Performance in Telecommunications", OECD Economic Studies (32): 99-142.

Cubbin, J. and J. Stern (2006), "The impact of regulatory governance and privatization on electricity industry generation capacity in developing economies", World Bank Economic Review, 20 (1): 115-141.

Fink, C., Mattoo, A. and R. Rathindran (2001), "Liberalizing Basic Telecommunications: The Asian Experience", The World Bank, Policy Research Working Paper Series: 2718.

Griliches, Z. (1957), "Hybrid Corn: An Exploration in the Economics of Technological Change", Econometrica, 25(4): 501-522.

Gual, J. and F. Trillas (2003), "Telecommunications Policies: Determinants and Impacts", IESE Working Paper, No.D/510, London Business School, University of Navarra.

Gutierrez, L. (2003a), "Regulatory Governance in the Latin American Telecommunications Sector," Utilities Policy, 11(4): 225-240.

Gutierrez, L. (2003b), "The Effect of Endogenous Regulation on Telecommunications Expansion and Efficiency in Latin America," Journal of Regulatory Economics, 23(3): 257-286.

Gutierrez, L.H. and S. Berg (2000), "Telecommunications liberalization and regulatory governance: lessons from Latin America," Telecommunications Policy, 24(10/11): 865-884. 
Hausman, J.A. (1975), "An Instrumental Variable Approach to Full Information Estimators for Linear and Certain Nonlinear Econometric Models", Econometrica, 43(4): 727-738

Hausman, J.A. (1978), "Specification Tests in Econometrics," Econometrica, 46(6): 1251-1271.

Hausman, J.A. and W.E. Taylor (1981), Panel Data and Unobserved Individual Effects , Econometrica, 49(6): 1377-1398.

ITU (2007), Market Information and Statistics on Global ICT development, on-line, available at: http://www.itu.int//TU-D/ict/statistics/ict/index.html, (latest update: $30^{\text {th }}$ October, 2008).

Laffont, J.J. and J. Tirole (2000), Competition in Telecommunications, MIT Press.

Levy, B. and P. Spiller (1994), "The Institutional Foundations of Regulatory Commitment: A Comparative Analysis of Telecommunications Regulation", Journal of Law, Economics and Organization, 10(2): 201-246.

Levy, B. and P.T. Spiller (eds.) (1996), Regulations, institutions, and commitment: Comparative studies of telecommunications, Cambridge: Cambridge University Press.

Li, W. and L.C. Xu (2002), "The Political Economy of Privatization and Competition Cross-Country Evidence from the Telecommunications Sector", Journal of Comparative Economics, 30(3): 439-462.

--- (2004), "The Impact of Privatization and Competition in the Telecommunications Sector around the World", Journal of Law and Economics, 47(2): 395-430.

Maiorano, F. and J. Stern (2007), "Institutions and telecommunications infrastructure in low and middle-income countries: The case of mobile telephony", Utilities Policy, Elsevier, 15(3): 165-181.

Mansfield, E. (1961), "Technical Change and the Rate of Imitation", Econometrica, 29(4): 741-766.

Megginson, W.L. and J.M. Netter (2001), "From State to Market: A Survey of Empirical Studies on Privatization", Journal of Economic Literature, 39(2): 321389.

McNary, R. (2001), "The Network Penetration Effects of Telecommunications Privatization and Competition", Public Policy, Stanford University, 58(x): 222235.

Parker, D. and C. KirkpatricK (2005), "Privatisation in Developing Countries: A Review of the Evidence and the Policy Lessons", Journal of Development Studies, 41(4): 513-541. 
Ros, A.J. (1999), "Does Ownership or Competition Matter? The Effects of Telecommunications Reform on Network Expansion and Efficiency", Journal of Regulatory Economics, 15(1): 65-92.

---- (2003), "The Impact of the Regulatory Process and Price Cap Regulation in Latin American Telecommunications Markets", Review of Network Economics, 2(3): 270-86.

Stern, J. and S. Holder (1999), "Regulatory Governance: Criteria for Assessing the Performance of Regulatory Systems", Utilities Policy, 8: 33-50.

Vickers, J. and G. Yarrow (1988), Privatization: An Economic Analysis, Cambridge, Massachusetts: The MIT Press.

Villalonga, B. (2000), "Privatization and Efficiency: Differentiating Ownership Effects from Political, Organizational, and Dynamic Effects", Journal of Economic Behavior \& Organization, 42(1): 43-74.

Wallsten, S.J. (2001), "An econometric analysis of Telecom competition, privatization and regulation in Africa and Latin America", Journal of Industrial Economics, 49(1): 1-20.

---- (2004), "Privatizing Monopolies in Developing Countries: The Real Effects of Exclusivity Periods in Telecommunications", Journal of regulatory economics, 26(3): 303-320.

Yarrow G. (1986), "Privatization in Theory and Practice", Economic Policy, 1(2): 323-377. 


\section{Appendix A}

The Number of Mobile Network Operators by Country from 1991 to 2006

\begin{tabular}{|c|c|c|c|c|c|c|c|c|c|c|c|c|c|c|c|c|c|}
\hline & & 1991 & 1992 & 1993 & 1994 & 1995 & 1996 & 1997 & 1998 & 1999 & 2000 & 2001 & 2002 & 2003 & 2004 & 2005 & 2006 \\
\hline 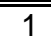 & "China & 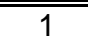 & $\bar{~} 1$ & 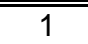 & 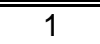 & 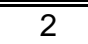 & 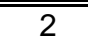 & 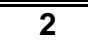 & 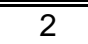 & 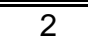 & 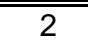 & 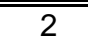 & 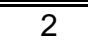 & 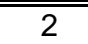 & $\overline{2}$ & 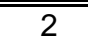 & 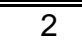 \\
\hline 2 & Australia & 1 & 1 & 1 & 3 & 3 & 3 & 3 & 3 & 3 & 4 & 4 & 4 & 5 & 5 & 5 & 5 \\
\hline 3 & Austria & 1 & 1 & 1 & 1 & 1 & 1 & 1 & 2 & 3 & 3 & 3 & 3 & 3 & 3 & 5 & 4 \\
\hline 4 & Belgium & 1 & 1 & 1 & 1 & 1 & 2 & 2 & 2 & 2 & 2 & 3 & 3 & 3 & 4 & 5 & 5 \\
\hline 5 & Canada & 2 & 2 & 2 & 2 & 2 & 2 & 3 & 4 & 4 & 4 & 4 & 4 & 4 & 4 & 5 & 6 \\
\hline 6 & Czech Republic & 1 & 1 & 1 & 1 & 1 & 1 & 2 & 2 & 2 & 2 & 3 & 3 & 3 & 3 & 3 & 4 \\
\hline 7 & Denmark & 1 & 1 & 2 & 2 & 2 & 2 & 2 & 2 & 4 & 4 & 4 & 5 & 5 & 5 & 5 & 4 \\
\hline 8 & Finland & 1 & 1 & 2 & 2 & 2 & 2 & 2 & 2 & 4 & 4 & 4 & 4 & 4 & 4 & 4 & 4 \\
\hline 9 & France & 2 & 2 & 2 & 2 & 2 & 2 & 2 & 2 & 2 & 2 & 3 & 3 & 3 & 4 & 4 & 4 \\
\hline 10 & Germany & 1 & 1 & 2 & 2 & 3 & 3 & 3 & 3 & 4 & 4 & 4 & 4 & 4 & 4 & 4 & 4 \\
\hline 11 & Greece & 0 & 0 & 2 & 2 & 2 & 2 & 2 & 2 & 3 & 3 & 3 & 3 & 3 & 3 & 3 & 3 \\
\hline 12 & Hungary & 1 & 1 & 1 & 1 & 2 & 2 & 2 & 2 & 2 & 2 & 4 & 3 & 3 & 3 & 3 & 3 \\
\hline 13 & Iceland & 1 & 1 & 1 & 1 & 1 & 1 & 1 & 1 & 2 & 2 & 2 & 3 & 3 & 3 & 3 & 4 \\
\hline 14 & Ireland & 1 & 1 & 1 & 1 & 1 & 1 & 1 & 2 & 2 & 2 & 3 & 3 & 3 & 3 & 3 & 4 \\
\hline 15 & Italy & 1 & 1 & 1 & 1 & 1 & 1 & 2 & 2 & 2 & 3 & 4 & 4 & 4 & 4 & 4 & 4 \\
\hline 16 & Japan & 2 & 2 & 2 & 2 & 2 & 3 & 4 & 4 & 4 & 4 & 4 & 4 & 4 & 4 & 5 & 5 \\
\hline 17 & Korea & 1 & 1 & 1 & 1 & 1 & 1 & 2 & 5 & 5 & 5 & 5 & 3 & 3 & 3 & 3 & 3 \\
\hline 18 & Luxembourg & 1 & 1 & 1 & 1 & 1 & 1 & 1 & 1 & 2 & 2 & 3 & 3 & 3 & 3 & 3 & 3 \\
\hline 19 & Mexico & 2 & 2 & 2 & 2 & 2 & 2 & 2 & 2 & 2 & 3 & 4 & 4 & 4 & 4 & 4 & 4 \\
\hline 20 & Netherlands & 1 & 1 & 1 & 1 & 1 & 1 & 2 & 2 & 4 & 5 & 5 & 5 & 5 & 5 & 5 & 6 \\
\hline 21 & New Zealand & 1 & 1 & 1 & 2 & 2 & 2 & 2 & 2 & 2 & 2 & 2 & 2 & 2 & 2 & 2 & 2 \\
\hline 22 & Norway & 1 & 1 & 1 & 2 & 2 & 2 & 2 & 2 & 2 & 2 & 2 & 2 & 2 & 2 & 2 & 2 \\
\hline 23 & Poland & 1 & 1 & 2 & 2 & 2 & 2 & 2 & 2 & 3 & 3 & 3 & 3 & 3 & 3 & 3 & 3 \\
\hline 24 & Portugal & 1 & 1 & 2 & 2 & 2 & 2 & 2 & 2 & 3 & 3 & 3 & 3 & 3 & 3 & 3 & 3 \\
\hline 25 & Spain & 1 & 1 & 1 & 1 & 2 & 2 & 2 & 2 & 2 & 3 & 3 & 3 & 3 & 3 & 3 & 3 \\
\hline 26 & Sweden & 2 & 2 & 3 & 3 & 3 & 3 & 3 & 3 & 3 & 3 & 4 & 4 & 4 & 4 & 4 & 4 \\
\hline 27 & Switzerland & 1 & 1 & 1 & 1 & 1 & 1 & 1 & 1 & 2 & 3 & 3 & 3 & 3 & 3 & 4 & 4 \\
\hline 28 & Turkey & 1 & 1 & 1 & 1 & 2 & 2 & 2 & 2 & 2 & 2 & 2 & 2 & 2 & 2 & 3 & 3 \\
\hline 29 & United Kingdom & 2 & 2 & 2 & 3 & 4 & 4 & 4 & 4 & 4 & 4 & 4 & 4 & 4 & 5 & 5 & 5 \\
\hline 30 & United States & 2 & 2 & 2 & 2 & 2 & 3 & 6 & 6 & 7 & 7 & 7 & 7 & 7 & 7 & 6 & 6 \\
\hline & Total & 36 & 36 & 44 & 49 & 55 & 58 & 67 & 73 & 88 & 94 & 104 & 103 & 104 & 107 & 113 & 116 \\
\hline & Average & 1.2 & 1.2 & 1.5 & 1.6 & 1.8 & 1.9 & 2.2 & 2.4 & 2.9 & 3.1 & 3.5 & 3.4 & 3.5 & 3.6 & 3.8 & 3.9 \\
\hline
\end{tabular}

Data source: compiled by author based on a variety of sources, including OECD regulatory database, countries' regulatory websites and firms' websites 


\section{Appendix B}

\section{Summary of Variables}

\begin{tabular}{|c|c|c|c|c|}
\hline & Ab. & Description & Sign expectation \& Interpretation & Source \\
\hline $\begin{array}{l}\text { Dependent } \\
\text { variable }\end{array}$ & $y_{i t}$ & $\begin{array}{l}\text { Logistically transformed } \\
\text { number of mobile } \\
\text { subscribers per } 100 \\
\text { inhabitants }\end{array}$ & - & ITU \\
\hline Reform variables & $\begin{array}{l}\text { itcNoFP } \\
\text { it } \\
\text { itclnP } \\
\text { it }\end{array}$ & $\begin{array}{l}\text { number of mobile network } \\
\text { operators, used to set entry } \\
\text { dummies } \\
\text { dummy variable for } \\
\text { independent regulator: } 1 \text {, if } \\
\text { created backed by legislation } \\
\text { and independent of decisions } \\
\text { making; } 0 \text {, otherwise; } \\
\text { dummy variable for } \\
\text { privatization: 1, if at least } \\
50 \% \text { of assets held by private } \\
\text { sector; } 0 \text {, otherwise; } \\
\text { interaction between the } \\
\text { number of entrants \& } \\
\text { privatization; between } \\
\text { interaction } \\
\text { independent regulator \& } \\
\text { privatization; }\end{array}$ & $\begin{array}{l}\text { positive } \\
\text { positive, pro-competition effects of } \\
\text { independent regulator }\end{array}$ & $\begin{array}{l}\text { ITU, WB, OECD, } \\
\text { regulators' \& MNOs' } \\
\text { websites }\end{array}$ \\
\hline \multirow{4}{*}{$\begin{array}{l}\text { Exogenous } \\
\text { control variables }\end{array}$} & $\operatorname{lnFxpn_{\text {it}}}$ & $\begin{array}{l}\text { The number of main lines per } \\
100 \text { inhabitants; }\end{array}$ & \multirow{4}{*}{$\begin{array}{l}\text { positive, if substitutes; negative, if } \\
\text { complements. } \\
\text { positive, as an indicator of network } \\
\text { technological advance; according to the } \\
\text { theory of technology diffusion, it is more } \\
\text { likely and faster for a technological } \\
\text { advanced country to move on and } \\
\text { adopt new network technology; hence, } \\
\text { better mobile network expansion and } \\
\text { efficiency will be expected in the } \\
\text { country where has more advanced } \\
\text { basic infrastructures. Alternatively, } \\
\text { because the positive network } \\
\text { externalities of the fixed network. } \\
\text { negative, larger population base offsets } \\
\text { number of mobile users when } \\
\text { penetration rates are estimated } \\
\text { positive, because the telecoms } \\
\text { capacity is better in urban areas than in } \\
\text { rural areas, and people living in urban } \\
\text { areas is considered to have a better } \\
\text { income, standard of living and a higher } \\
\text { awareness of adopting new technology; } \\
\text { consequently, the larger is the urban } \\
\text { population, the higher is the mobile } \\
\text { subscribers, and then the higher is the } \\
\text { mobile penetration. } \\
\text { positive, a proxy of technological } \\
\text { progress; also, capture the diffusion of } \\
\text { mobile network (i.e. network increases } \\
\text { over time) during the period we study. }\end{array}$} & ITU \\
\hline & $\operatorname{lnGDPpc} c_{\text {it }}$ & per capita GDP; & & IMF \\
\hline & InPop ${ }_{i t}$ & $\begin{array}{l}\text { urban population as a \% of } \\
\text { total national population; }\end{array}$ & & WBG-HNP, OECD \\
\hline & $\mathrm{t}$ & time trend; & & \\
\hline \multirow[t]{2}{*}{$\begin{array}{l}\text { Instrumented } \\
\text { variables }\end{array}$} & InMSps it & $\begin{array}{l}\text { The number of mobile } \\
\text { subscribers served per } \\
\text { mobile staff }\end{array}$ & $\begin{array}{l}\text { positive, higher labour productivity } \\
\text { implies the technological advance in the } \\
\text { production process that can lead to } \\
\text { better services quality (e.g. better } \\
\text { technical supports and better network } \\
\text { capacity), which can attract more } \\
\text { people to access mobile network } \\
\text { services, and thus, result in increase in } \\
\text { mobile penetration. }\end{array}$ & \multirow[t]{2}{*}{ ITU \& MII } \\
\hline & $\operatorname{lnMbp}_{\text {it }}$ & $\begin{array}{l}\text { mobile price of 3-minute local } \\
\text { call }\end{array}$ & $\begin{array}{l}\text { negative, higher own-price is } \\
\text { associated with lower demand }\end{array}$ & \\
\hline \multirow{2}{*}{$\begin{array}{l}\text { Additional } \\
\text { instrumental } \\
\text { variables }\end{array}$} & $\ln T \mathrm{Ir}_{\text {it }}$ & $\begin{array}{l}\text { annual telecoms investments } \\
\text { as a \% of gross capital } \\
\text { formation }\end{array}$ & $\begin{array}{l}\text { positive, higher investments can } \\
\text { promote productivity in general, and } \\
\text { investments in more advanced network } \\
\text { technologies and equipments as well as } \\
\text { training programmes can improve } \\
\text { labour productivity in particular. }\end{array}$ & \multirow{2}{*}{ ITU } \\
\hline & $\begin{array}{l}\text { InCpuit } \\
\text { InL1Mbp } \\
\end{array}$ & $\begin{array}{l}\text { cost per unit in moblle } \\
\text { services, i.e. } \\
\text { investments per mobile } \\
\text { subscribers mobile } \\
\text { 1-lagged mobile price of } 3 \text { - } \\
\text { minute local call }\end{array}$ & $\begin{array}{l}\text { positive, higher average costs is } \\
\text { incentive to set higher prices }\end{array}$ & \\
\hline
\end{tabular}

1. All explanatory variables are in logarithmic form, except for time trend and dummies. 


\section{Appendix C}

\section{Correlations between regulatory variables and mobile penetration}

\begin{tabular}{|c|c|c|c|c|c|c|c|}
\hline & $y$ & $\mathrm{NoF}$ & prvt & sprtrg & itcSP & itcNoFP & itcNoFS \\
\hline$y$ & 1.00 & & & & & & \\
\hline NoF & $\begin{array}{l}0.64 \\
0.00\end{array}$ & 1.00 & & & & & \\
\hline prvt & $\begin{array}{l}0.59 \\
0.00\end{array}$ & 0.52 & 1.00 & & & & \\
\hline sprtrg & $\begin{array}{l}0.56 \\
0.00\end{array}$ & $\begin{array}{l}0.50 \\
0.00\end{array}$ & $\begin{array}{l}0.40 \\
0.00\end{array}$ & 1.00 & & & \\
\hline itcSP & $\begin{array}{l}0.58 \\
0.00\end{array}$ & $\begin{array}{l}0.52 \\
0.00\end{array}$ & $\begin{array}{l}0.72 \\
0.00\end{array}$ & $\begin{array}{l}0.77 \\
0.00\end{array}$ & 1.00 & & \\
\hline itcNoFP & $\begin{array}{l}0.65 \\
0.00\end{array}$ & $\begin{array}{l}0.83 \\
0.00\end{array}$ & $\begin{array}{l}0.85 \\
0.00\end{array}$ & $\begin{array}{l}0.45 \\
0.00\end{array}$ & $\begin{array}{l}0.72 \\
0.00\end{array}$ & 1.00 & \\
\hline itcNoFS & $\begin{array}{l}0.60 \\
0.00\end{array}$ & $\begin{array}{l}0.78 \\
0.00\end{array}$ & $\begin{array}{l}0.45 \\
0.00\end{array}$ & $\begin{array}{l}0.86 \\
0.00\end{array}$ & $\begin{array}{l}0.77 \\
0.00\end{array}$ & $\begin{array}{l}0.66 \\
0.00\end{array}$ & 1.00 \\
\hline
\end{tabular}

The correlations between these variables are all significant at $1 \%$.

\section{Average mobile penetration by regulatory practices}

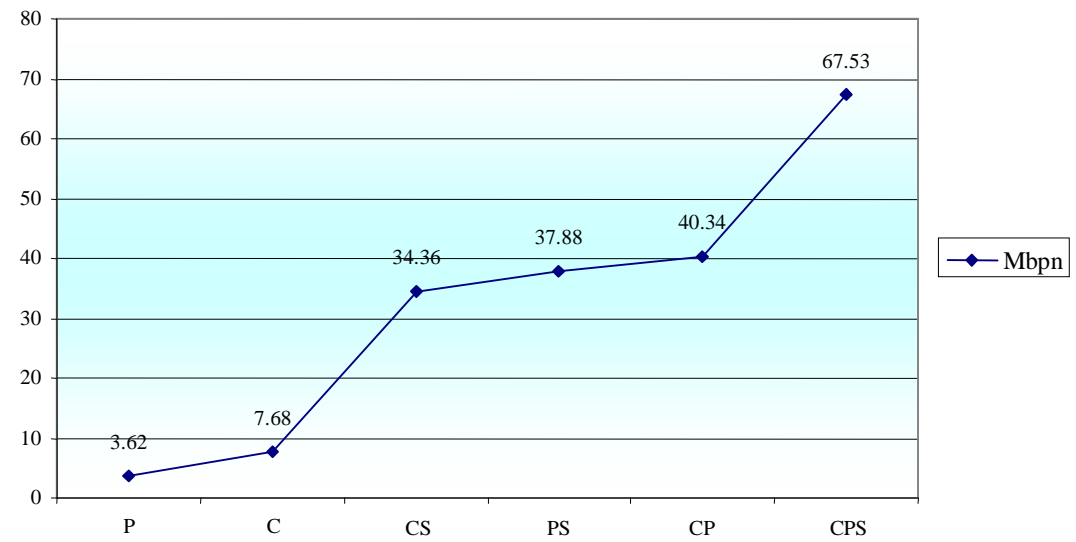

$\boldsymbol{P}:$ the mobile market is characterized by private monopoly, without a separate regulator;

$\boldsymbol{C}$ : the mobile market is characterized by public ownership and operates in a competitive environment, without a separate regulator;

PS: the mobile market is characterized by private monopoly, with a separate regulator;

CS: the mobile market is characterized by public ownership and operates in a competitive environment, with a separate regulator;

CP: the mobile market is characterized by private ownership and operates in a competitive environment, without a separate regulator;

CPS: the mobile market is characterized by private ownership and operates in a competitive environment, with a separate regulator. 